\title{
Testing the Maximum Entropy Production approach for estimating evapotranspiration from closed canopy shrubland in a low-energy humid environment
}

\begin{tabular}{|r|l|}
\hline Journal: & Hydrological Processes \\
\hline Manuscript ID & HYP-17-0444.R2 \\
\hline Wiley - Manuscript type: & Scientific Briefing \\
\hline Date Submitted by the Author: & n/a \\
\hline Complete List of Authors: & $\begin{array}{l}\text { Wang, Hailong; University of Aberdeen, School of Geosciences } \\
\text { Tetzlaff, Doerthe; University of Aberdeen, Northern Rivers Institute, School } \\
\text { of Geosciences } \\
\text { Soulsby, Chris; University of Aberdeen, School of Geosciences }\end{array}$ \\
\hline Keywords: & $\begin{array}{l}\text { evapotranspiration, water balance, interception, climate change, northern } \\
\text { uplands, maximum entropy production }\end{array}$ \\
\hline
\end{tabular}

\section{SCHOLARONE ${ }^{\text {TH }}$}

Manuscripts 
$1 \quad$ Testing the Maximum Entropy Production approach for estimating

2 evapotranspiration from closed canopy shrubland in a low-energy humid

environment

4

5 Hailong Wang*, Doerthe Tetzlaff, Chris Soulsby

6

7 Northern Rivers Institute, School of Geosciences, University of Aberdeen, AB24 3UE,

$8 \quad$ United Kingdom

$9 \quad *$ corresponding to hailong.wang@abdn.ac.uk; wh184@,hotmail.com; +44 1224272342

10

11 Emails of co-authors:

12 Doerthe Tetzlaff: d.tetzlaff@abdn.ac.uk

13 Chris Soulsby: c.soulsby@abdn.ac.uk

14 
15 Abstract: Quantifying and partitioning evapotranspiration $(E T)$ into evaporation $(E)$

16 and transpiration $(T)$ is challenging but important for interpreting vegetation effects on

17 the water balance. We applied a model based on the theory of maximum entropy

18 production (MEP) to estimate $E T$ for shrubs for the first time in a low-energy humid

19 headwater catchment in the Scottish Highlands. In total, 53\% of rainfall over the

20 growing season was returned to the atmosphere through $E T$ ( $59 \pm 2 \%$ as transpiration),

21 with $22 \%$ of rainfall ascribed to interception loss and understory $E T$. The remainder of

22 rainfall percolated below the rooting zone. The MEP model showed good capability for

23 total ET estimation, in addition to providing a first approximation for distinguishing $E$

24 and $T$ in such ecosystems. This study shows that this simple and low-cost approach has

25 potential for local to regional ET estimation with availability of high-resolution

26 hydroclimatic data. Limitations of the approach are also discussed.

27 Key words: evapotranspiration; water balance; interception; climate change; northern 28 uplands; maximum entropy production 
30

31 Northern high latitude ecosystems are experiencing amplified climate warming

32 (Serreze and Barry, 2011; IPCC, 2014) which has led to changes in the composition,

33 density and distribution of vegetation communities in recent decades (Elmendorf et al.,

34 2012); for example, a northward advance of the tree-line replacing tundra shrubs

35 (Serreze and Barry, 2011; Yu et al., 2014). Future drying and warming in growing

36 seasons (Lindner et al., 2008) may lead to a reduction in subsurface water storage and

37 streamflow due to increasing evapotranspiration (ET). In water-limited areas, annual

38 ET can account for over $90 \%$ of precipitation (Wilcox et al., 2006). Whilst the

39 evaporation $(E)$ component of $E T$ is essentially a water loss, transpiration $(T)$ is

40 related to biomass production (Kool et al., 2014), though constrained by both plant

41 physiological and environmental factors such that stomata can respond to stress

42 imposed by high vapor pressure deficit or low root-zone soil water content (Wang et

43 al., 2014). The proportion of $E$ dominates over bare soil and sparsely vegetated

44 surfaces (Lu et al., 2017); while $T$ is usually greater over densely vegetated areas and

45 in energy limited regions (Miralles et al., 2011; Schlesinger and Jasechko, 2014).

46 Estimating and partitioning ET is crucial to provide evidence for sustainable water

47 management that targets high water use efficiency, especially in a time of marked 48 environmental change.

49 Whilst the physics are understood (Brutsaert, 1982; Allen et al., 1996), we still have 
50 difficulties in estimating actual ET in the landscape. Kool et al., (2014) summarized

51 ET partitioning methods ranging from field measurements to remote sensing

52 algorithms. Eddy covariance and Bowen ratio techniques commonly provide total

53 over-canopy ET measurements mostly in flat terrain and for homogeneous vegetation

54 covers (Baldocchi et al., 2001). Other methods such as sap flow measurements

55 (Granier, 1987) and mass balance of stable isotopes (Sutanto et al., 2012) can provide

56 separate estimates of $E$ and $T$. However, such field techniques are often difficult to

57 extrapolate to a broader scale, and have high costs to setup and maintain instruments,

58 particularly in remote areas with complex topography and heterogeneous vegetation

59 cover (Caylor et al., 2006). Surface energy balance-based remote sensing algorithms

60 (e.g., Shuttleworth and Wallace, 1985) can provide long-term ET estimates for large

61 spatial areas, but usually are not able to provide $E T$ at high spatiotemporal resolutions

62 due to low satellite orbiting frequency and high cloud cover (Shwetha and Kumar,

63 2015) in some high latitude regions. Hydrological models can help understand

64 interlinkages between different water balance components, though such models

65 usually require large input datasets (Chen et al., 2007) to calibrate parameters (often

66 unidentifiable) commonly against streamflow (van Huijgevoort et al., 2016). ET

67 parameterization in such models is either overly simple (e.g., van Huijgevoort et al.,

68 2016) or extremely complex (e.g., Noilhan and Planton, 1989).

69 Recently, a novel and simple approach for ET estimation was proposed based on the 
70 theory of maximum entropy production (MEP), and tested over dry land surfaces

71 (Wang and Bras, 2009, 2011). The model only requires net radiation $(R n)$, temperature

72 and specific humidity measured at soil and canopy surfaces for $E$ and $T$ estimation

73 respectively. The model differs to conventional bulk transfer approaches in several

74 ways (Bras, 2015): water and energy fluxes are estimated without using temperature

75 and humidity gradients; wind speed and surface roughness are not needed to

76 parameterize turbulent transport; and surface energy balance is always and

77 automatically conserved. Notably, previous application of the MEP model was

78 focused on either bare soil for evaporation or full vegetation cover for transpiration.

79 Whilst total ET estimation using the MEP model over vegetated surfaces can

80 substantially reduce measurement efforts, the approach has not yet been fully tested.

81 Here, we focus on a humid, low-energy heather (Calluna vulgaris and Erica tetralix)

82 shrub ecosystems in NE Scotland (Tetzlaff et al., 2015). Heather moorland is the third

83 most extensive land cover in the UK (Stewart et al., 2008), and the characteristics of

84 its growth, development and ecology have been well documented (Gimingham, 1960;

85 MacDonald et al., 1995). However, the potential effects of the complex nature of

86 heather canopy on water and energy exchange with atmosphere are not well

87 investigated, and studies on water use and interception in heather-dominated areas are

88 limited to several in the British uplands around 1980s and 1990s (Wallace et al., 1982;

89 Calder et al., 1984; Miranda et al., 1984; Calder, 1986; Dunn and Mackay, 1995; 
90 Haria and Price, 2000). Though annual ET is usually modest compared to other water

91 budget components in the Scottish Highlands (Soulsby et al., 2015), its quantification

92 is crucial for assessing the role of land use in water fluxes and stores (Calder, 1986;

93 Ladekarl et al., 2005). Therefore, in this study we applied the MEP model to test its

94 capability for providing total ET estimation and partitioning in such an ecosystem.

95 Subsequently, we quantified the water budgets to enhance our understanding of the

96 vegetation effects on water partitioning in terms of $T, E$ and deep percolation. We also

97 discussed the strengths and weaknesses of the approach in this environmental setting.

\section{2. Data and Methods}

$99 \quad$ 2.1. Study site and measurements

100 The Bruntland Burn $\left(57.04^{\circ} \mathrm{N}, 3.13^{\circ} \mathrm{W}\right.$, Figure 1) in the Scottish Highlands represents a

101 low-energy, high-humidity headwater catchment in northerly latitudes at the

102 temperate/boreal transition (Tetzlaff et al., 2014; Soulsby et al., 2015). The catchment

103 has an elevation of 250-500 m.a.s.1, with gentle slopes across most areas and only steep

104 slopes in the upper areas. Annual precipitation $(P)$ is over $1000 \mathrm{~mm}$ of which only $<5 \%$

105 is snow. There are no distinct dry and wet seasons since $P$ is fairly evenly distributed

106 throughout the year, with a monthly average of $74 \pm 15 \mathrm{~mm}$ and a median of $68 \mathrm{~mm}$ over

107 the last three decades. Annual mean air temperature $(T a)$ is $\sim 6^{\circ} \mathrm{C}$ and relative humidity

$108(R H)$ is $\sim 80 \%$. Annual mean runoff at the outlet is $\sim 700 \mathrm{~mm}$ (Soulsby et al., 2015).

109 Winds are commonly moderate to strong, thus, vigorous turbulence often occurs over 
110 the landscape. The majority of the catchment is covered by $0.3-0.6 \mathrm{~m}$ tall, dense

111 closed-canopy heather overlying podzolic soils. Heather shrubs are evergreen with

112 most roots in the upper $10 \mathrm{~cm}$ of the soils. Sphagnum spp. moss and other bryophytes

113 form a dense understory beneath densely layered woody stem and branch networks of

114 heather supporting the evergreen leaves. This results in very low light penetration

115 through vegetation to the soil surface. Scots pine forest (Pinus sylvestris) is restricted

116 to inaccessible steeper hillslopes and plantations near the catchment outlet, covering

$117<10 \%$ of total catchment area. The riparian zones are covered by Sphagnum moss and 118 grass (Molinia caerulea).

120 iButton sensors (DS1923 model, Maxim Integrated, USA) were attached to bamboo

121 sticks hanging directly above the heather canopy ( $<5 \mathrm{~cm}$ from the top) (Figure 1c) to

122 measure temperature and relative humidity $(R H)$. The iButton sensors have a precision

123 of $\pm 0.5^{\circ} \mathrm{C}$ and $\pm 5 \%$ for temperature and $R H$, respectively. Sensors were shielded by two

124 layers of white plastic bowls with the top layer wrapped by thick aluminum foils to

125 avoid radiation influence while ensuring ventilation. To account for spatial variability

126 of temperature and humidity above the heather canopy, 15 sensors were set up $2 \mathrm{~m}$ apart

127 in an array of 3 by 5 in a representative plot, recording data every $30 \mathrm{~min}$. In addition,

128 air temperature $(T a), R H$, net radiation $(R n)$, ground heat flux $(G)$, wind speed/direction, 
129 and air pressure were collected from an automatic weather station (1.8 $\mathrm{m}$ above ground)

$130 \quad 100 \mathrm{~m}$ away at 15 -min intervals.

131 Data were collected during two time periods (TP) over one calendar year: 31/07 to

$13231 / 10$ in 2015 (TP15), and 21/04 to 04/08 in 2016 (TP16). In addition, 22 throughfall

133 collectors were placed under the heather canopies during 01/06-24/09 in 2015 to

134 measure throughfall on a weekly basis (Braun et al., 2016). Collectors comprised an

135 inner measuring cylinder, an open orifice with a mesh screen (to prevent leaf/litter

136 blockage) that funnels throughfall to the cylinder, and a bottom supporting part buried

137 in ground.

138 2.2. Methods

139 The MEP model formulates the entropy production function to include the latent heat

140 flux term. Maximization of the function under the constraint of energy conservation

141 leads to a unique partition of net radiation into latent, sensible and ground heat fluxes

142 for different surfaces (Wang and Bras, 2009, 2011). In this study, we adapted the model

143 for transpiration ( $T$ ) estimation in equations (1-3):

144

$$
\begin{array}{r}
T=\frac{k_{u} \cdot R n c}{\lambda\left(1+B^{-1}(\sigma)\right)} \\
B(\sigma)=6\left(\sqrt{1+\frac{11}{36} \sigma}-1\right)
\end{array}
$$




$$
\sigma\left(T_{c}, q_{c}\right)=\frac{\lambda^{2}}{c_{p} R_{v}} \frac{q_{c}}{T_{c}^{2}}
$$

147 Where $k_{u}$ is for unit conversion, equals to $3.6 \times 10^{6}$ for transpiration in $\mathrm{mm} / \mathrm{h}$. Rnc is net

148 radiation at the canopy $\left[\mathrm{W} / \mathrm{m}^{2}\right] . \lambda$ is latent heat of vaporization $[\mathrm{J} / \mathrm{kg}] . B(\sigma)$ is the

149 reciprocal of the Bowen ratio. $\sigma$ characterizes the phase-change related state of the

150 evaporating surface, as a function of temperature $\left(T_{c}\right.$, in $\left.{ }^{\circ} \mathrm{C}\right)$ and specific humidity $\left(q_{c}\right.$,

151 in $\mathrm{kg} / \mathrm{kg}$ ) at the canopy surface, which in this study were the iButton measurements. $c_{p}$

152 is the specific heat capacity of air at constant pressure $\left[1013 \mathrm{~J} /\left(\mathrm{kg}^{\circ} \mathrm{C}\right] . R_{v}\right.$ is the gas

153 constant for water vapor $\left[461.5 \mathrm{~J} /\left(\mathrm{kg}^{\circ} \mathrm{C}\right)\right]$. Transpiration was calculated at hourly

154 intervals and then summed up to daily values. Night-time transpiration was assumed

155 zero because $T$ in this environment is primarily controlled by radiation (Wang et al., 156 2017).

$157 R n c$ was not directly measured but estimated based on Beer's law: $R n c=R n \cdot\left(1-e^{-\kappa \cdot L A I}\right)$,

158 where $R n$ is net radiation measured at the weather station. Beer's law has been

159 commonly used for solar radiation allocation for canopy and soil (e.g., Ritchie, 1972;

160 Wang et al., 2014a). It has been found that the $R n$ intercepted by canopy can also be

161 calculated using the Beer's law (Ross, 1981; Shuttleworth and Wallace, 1985; Yang et

$162 a l ., 2013)$, since $R n$ during daylight hours is primarily determined by the solar radiation,

163 and net longwave radiation is dependent on surface-air temperature difference which is

164 small in the catchment. $L A I$ (leaf area index) measured using a plant canopy analyzer

165 LAI-2200C (LI-COR Environmental, USA) was 3.0 which is unrealistically high, 
166 because the optical sensor placed at the bottom of heather plants viewed not only the

167 small leaves but also the well-developed stems and highly layered branches from

168 bottom to top (Figure 1d, e). We therefore adopted the value of 1.7 from Calder et al., 169 (1984) derived for a similar environment. Average LAI extracted from MODIS

170 products (500m, 8-day) in 2015 was 1.9 (Myneni and Park, 2015) comparable to the

171 value used. $\kappa$ is the light extinction coefficient prescribed as 0.56 , the average value for

172 global shrublands (Zhang et al., 2014). LAI and $\kappa$ are influenced by canopy structure,

173 leaf angle, solar angle (De Costa et al., 1992). A sensitivity analysis is given in Figure

174 S1 in Supplementary Materials, which shows that variations in $T$ and $T / E T$ ratio were

175 sensitive to $\kappa \cdot L A I$ (e.g. an increase in $\kappa \cdot L A I$ by $10 \%$ will cause a $0.04 \mathrm{~mm} / \mathrm{d}$ increase

176 in $T$ and $3.5 \%$ increase in $T / E T$ ratio, respectively). However, heather is a slow

177 growing evergreen species (Gimingham, 1960), and once mature, its canopy structure

178 changes little. The setting of a constant $L A I$ and $\kappa$ for a 12 months period was

179 therefore deemed reasonable for this site.

180 To estimate the total ET over the vegetated surface with the MEP model, we used Ta,

$181 R H$, and $R n, G$ measured at a nearby weather station \#1 (Figure 1). Comparisons of

182 vapor pressure deficit at 3 weather stations in the catchment across a range of

183 elevations (250-360 m.a.s.1, Figure S2 in Supplementary Materials) confirmed that

184 there is a vapor equilibrium from the weather station $\# 1$ to an altitude $\sim 100 \mathrm{~m}$ above.

185 This indicates that the humid air is usually sufficiently mixed by winds from above 
186 the heather canopies to higher levels, ensuring the ET based on measurements at the

187 weather station representative in the area. Evaporation $(E)$ was calculated as the 188 difference between $E T$ and $T$. Note that this $E$ is theoretically likely composed of soil 189 evaporation, moss transpiration and interception loss.

190 To test the ET estimates from the MEP model, results were compared to those derived

191 from more commonly used approaches. We used the FAO crop coefficient $(K c)$

192 method which has been used for ET estimation for various vegetation communities

193 (Cammalleri et al., 2013; Rosa et al., 2016). Kc (0.70) was estimated from the MODIS

194 8-day ET product during the growing seasons of 2015 and 2016 (Mu et al., 2011) in

195 the study site pixel which is mostly covered by heather. The $K c$ value is consistent

196 with Johnson (1991) for a similar catchment in central Scotland, and previous

197 modeling work in the study catchment (Ala-aho et al., 2017). Two methods were used

198 to calculate the potential evapotranspiration $(p E T)$ using meteorological data at the

199 weather station \#1: the Penman-Monteith equation (Allen et al., 1998), denoted as

$200 p E T_{P M}$; and the Priestley-Taylor equation (Priestley and Taylor, 1972), denoted as

$201 p E T_{P T}$. The Priestley-Taylor coefficient was set to the default value 1.26. Transpiration

202 was compared to that derived from the widely applied Hydrus-1D model (Šimůnek et

203 al., 2012). Soil hydraulic parameters were obtained from inverse modeling using the

204 soil moisture observations at three depths. Inverse results (Figure S3 in

205 Supplementary Materials) show that water balance estimates with Hydrus reproduced 
206 the variations in soil moisture with $R^{2} \geq 0.61$ and root mean square error of 0.02

$207 \mathrm{~cm}^{3} / \mathrm{cm}^{3}$ for all three depths. This gives an independent comparison for the MEP 208 results. More information of the Hydrus model setup, ancillary sampling and 209 measurements can be found in the Supplementary Materials.

210 Lastly, the water balance between observed rainfall and the MEP-estimated ET was

211 calculated, to understand the role of heather in water partitioning in terms of 212 transpiration and rainfall interception, and potential recharge to subsurface water 213 storage.

214 3. Results

$215 \quad 3.1$ Daily dynamics of hydroclimatic variables

$216 \quad<$ Figure 2 here $>$

217 The two periods shared similar characteristics of temperature and humidity. Monitoring 218 in 2015 (TP15, 93 days) coincided with cooling down from mid-summer to autumn 219 with a mean daily $T a$ of $10.1 \pm 2.9^{\circ} \mathrm{C}$ (mean \pm one standard deviation), while TP16 (106 220 days) was the spring warm up with a mean $T a$ of $10.6 \pm 3.6^{\circ} \mathrm{C}$ (Figure $2 \mathrm{a}$ ). $R H$ was 221 generally high during the two periods, averaging $80.7 \pm 7.0 \%$ and $76.1 \pm 8.0 \%$, 222 respectively. Rainfall in the two periods (167.2 and $292.2 \mathrm{~mm}$ ) was $33 \%$ less and 30\% 223 more than the recent decadal average respectively. Net radiation $(R n)$ decreased 
224 gradually in TP15 while large variation characterized TP16 mainly due to frequent

225 rainfall and associated clouds. Evapotranspiration was primarily restricted by energy, 226 reflected by a strong positive linear relationship between $p E T$ and $R n\left(R^{2} \geq 0.87\right.$, $227 p<0.001)$, followed by relative humidity $\left(R^{2} \geq 0.63, p<0.001\right) . p E T$ estimated by 228 Priestley-Taylor equation is higher than that by Penman-Monteith equation.

\subsection{Evapotranspiration and its partitioning}

230

$<$ Figure 3 here $>$

231 Estimated ET and its components (Figure 3a-b) exhibited similar dynamics, and were 232 generally higher in TP16 (spring/summer) than TP15 (summer/autumn). Variation of $233 E T$ were consistent with radiation and $p E T$ in Figure 2. In total, estimated heather $T$ $234(143.1 \mathrm{~mm})$ was about 1.4 times higher than $E(101.5 \mathrm{~mm})$. The $T / E T$ ratio during the 235 entire study period varied from 0.55 to 0.66 , with the average of $0.59 \pm 0.02$ and median 236 of 0.59 , consistent in TP15 and TP16. T/ET ratio was generally high on rainy days when $237 E$ was low and then became smaller on days after rain when the proportion of 238 interception loss increased. The bands in Figure $3 \mathrm{~b}$ demonstrate the upper and lower 239 bounds for $E$ and $T$ based on standard deviation of daily $T c$ and $R H$. E increased on days 240 shortly after rain, and then decreased towards zero when rain-free days were long 241 enough. The $T / E T$ ratio is also affected by the $L A I$ and light extinction coefficient $\kappa$ 242 (Figure S1). The sensitivity analysis shows that when $\kappa \cdot L A I$ is increased by $10 \%, T$ 243 increases by $0.04 \mathrm{~mm} / \mathrm{d}$ and the $T / E T$ ratio by 0.03 ; an increase of $\kappa \cdot L A I$ by $50 \%$ results 
244 in an increase of $0.17 \mathrm{~mm} / \mathrm{d}$ in $T$ and 0.14 in the $T / E T$ ratio. As heather is a slow 245 growing evergreen species and around 20 years old at the study site, an increase in the $246 \kappa \cdot L A I$ by $50 \%$ gives an extreme illustration of potential effects, as such rapid growth 247 would be impossible. Further, when $L A I$ increases with vegetation growth, the total $E T$ 248 usually also increases (Hu et al., 2008). However, in this sensitivity analysis ET is 249 calculated in the MEP model from hydroclimatic measurements at the weather station 250 and therefore excludes vegetation growth effects on $E T$ in the $\kappa \cdot L A I$ increasing 251 scenarios.

252 The comparison of ET and $T$ estimated by alternative methods showed that the MEP 253 approach gave comparable estimations (Figure 3c-e). The crop coefficient method 254 showed a good agreement with the MEP model for ET estimation when $p E T$ was 255 calculated with the Penman-Monteith equation $\left(R^{2}=0.92\right.$ and a slope of 0.94$)$. Using the 256 potential ET from the Priestley-Taylor equation, however, overestimated ET by about $25721 \%$ compared to the MEP model, showing a linear regression slope of 0.79 and $258 R^{2}=0.98(p<0.001)$. This may indicate that the default Priestley-Taylor coefficient $(1.26)$ 259 is too high for this site. Regarding transpiration, the MEP model gave consistent results 260 to the Hydrus-1D simulations, showing a linear regression slope of $0.88\left(R^{2}=0.74\right.$, $261 p<0.001)$. 
262

263

264 A summary of rainfall, ET and its components, and potential percolation for the two 265 study periods is given in Table 1. Based on the observations and the MEP modelling 266 results, there was a total of $459.4 \mathrm{~mm}$ rainfall over the two periods, and $53.3 \%$ was 267 returned to the atmosphere through $E T$. It is worth mentioning that $E$ in this case 268 comprised soil evaporation $(E s)$, moss transpiration $\left(T_{m}\right)$ and interception loss $(E i)$. Es 269 and $T_{m}$ can be very small because of low light penetration to the soil surface caused by 270 the heather structure. Therefore, majority of the $22.1 \%$ of rainfall is most likely 271 attributable to $E i$ from both heather leaves and stems. Summer surface runoff at the site 272 does not occur due to flat terrain, low intensity of rainfall and high infiltration capacity, 273 consequently $46.7 \%$ of rainfall percolated to the underlying soil/groundwater.

\section{4. Discussion}

276 Previous studies using the MEP model (Wang and Bras, 2011) focused on $E$ and $T$

277 estimations from bare soil and full vegetation surfaces at the plot scale. In this study, the

278 agreement of ET from different methods suggests that the MEP model also has potential

279 for estimating total ET over extensive homogenous vegetated surfaces. It is notable that

280 the comparison in Figure $3 \mathrm{c}$ indicates that the default Priestley-Taylor coefficient 15 
$281 \alpha=1.26$ was too high for our site; $\alpha$ is usually smaller in humid areas (Weiß and Menzel, 282 2008). To accommodate the actual ET estimation using the crop coefficient method, $283 \alpha=1.05$ would be more realistic for our site (with a linear regression slope of 0.99 and $284 R^{2}=0.98$ ), which is consistent with other work in upland areas dominated by shrubs 285 (Engstrom et al., 2002).

286 To ensure the meteorological measurements at the weather station capture the total ET 287 fluxes at this specific site, a vapor equilibrium from above the canopy to the level where $288 T a, R H$ and $R n$ were measured is required. This is similar to the practical setup of an 289 eddy covariance tower (Baldocchi et al., 2001) to account for the contribution of soil 290 and vegetation to the total ET flux within a suitable footprint. By comparing the vapor 291 pressure deficit at 3 weather stations (Figure S2) located at different elevations in the 292 catchment, we can confirm this equilibrium in our humid environment, at least from the 293 weather station \#1 to nearly $100 \mathrm{~m}$ higher. In this sense, this study potentially extends 294 the application of the MEP model from a plot scale assessment of $E$ and $T$ from bare 295 soils and vegetation canopies to $E T$ estimation over a spatially extensive vegetated 296 surface. One such integrated set of meteorological measurements at an appropriate 297 height can be more cost-effective compared to concurrent measurements at both the soil 298 and canopy surfaces. With the increasing availability of high-resolution assimilation 299 data of $T a, q$ and $R n, G$ (Liston and Elder, 2006), and remote sensing techniques for 300 partitioning land surface temperature into soil surface temperature and canopy surface 
301 temperature (Yang and Shang, 2013), this may provide a step towards a feasible and

302 efficient tool to map local to regional ET over more heterogeneous surfaces.

\section{2. $E T$ partitioning and canopy water balance}

304 Despite the promising potential of the MEP model for total ET estimation, there are two 305 major limitations in this study. Firstly, the difficulty of dividing $E$ into specific 306 components including Ei, Es, and $\mathrm{Tm}$. Considering the high fractional vegetation cover, 307 the dense closed heather canopy, and the high stem and branch density (MacDonald et 308 al., 1995) that effectively attenuate light penetration, Es and Tm were expected to be 309 small. From the perspective of energy balance, under-canopy available energy was $38.6 \%$

310 of the total based on the Beer's law. Most of this radiation is intercepted by the layered 311 stems and branches, and partly used to evaporate intercepted water when present; the 312 rest was sensible heat to warm up the air. A very recent soil water isotope analysis

313 shows that $E s$ was $<5 \%$ of net precipitation (Sprenger et al., 2017), equivalent to 3\% of 314 gross rain. Therefore, majority of $E(22.1 \%$ of rainfall $)$ over the entire study period 315 would have been $E i$, which is lower than the average estimate ( $28 \%$ of rainfall) for a 316 catchment mixed with trees and shrubs near the Scotland-England border (Robinson et 317 al., 1998).

318 Secondly, there is a difficulty in completely distinguishing canopy evaporation from 319 transpiration under wet conditions, because the iButton sensed $T a$ and $R H$ will likely 
320 include the influence of both $T$ and $E i$. The rainy day time (7:00-19:00) represented

321 only $6.8 \%$ of the total day time (based on 15 -min measurements). However, during

322 such times, the site received $>63 \%$ of the total rainfall. Apart from stemflow, the rest of

323 interception would have been on the leaves and stems. The water on leaves evaporates

324 first in a short time after rains when there is available energy, followed by transpiration.

325 This is believed to be the main period when the effects of evaporation and transpiration

326 on iButton sensed $T c$ and $R H$ coexist. Storage on stem surfaces will evaporate with

327 energy available below the canopy, but this process should not affect the measurements

328 too much because of the sensors positions. This part of interception loss would have

329 been the main source of $E$ in addition to $E s$ and $T m$ on rain-free days. Direct throughfall

330 measurements in June-September 2015 indicated about $38 \%$ of rain was intercepted

331 though stemflow was not measured (Braun et al., 2016). The estimated Ei was $20.8 \%$ of

332 rainfall when both $E s$ and $T m$ are assumed as 3\% in the similar period. The difference

333 could be explained by stemflow along the heather $(17.2 \%)$ which is higher than some

334 desert shrubs ( 9\%) (Li et al., 2016), but within the range for European shrubs (Llorens

335 and Domingo, 2007).

336 Over the entire study period, the residual rainfall (46.7\%) after ET loss percolated into

337 the deeper soils, because surface runoff is negligible at the study plot due to the flat

338 terrain and permeable podzolic soils (Tetzlaff et al., 2007). Based on previous studies

339 using geophysical surveys (Soulsby et al., 2016) and a tracer-aided model (Birkel et al., 
340 2011), most of the excess rainfall beyond ET becomes storage in soils; then may later

341 recharge groundwater (Tetzlaff et al., 2007), and contribute to downslope riparian

342 zones and streams through subsurface lateral flow (Blumstock et al., 2016). The

343 MEP-derived water balance highlights the qualitative and quantitative effects of

344 vegetation on water partitioning and storage in heather dominated areas like the study

345 site. This provides a benchmark for assessing the effects of land use change from

346 management effects or projected future warmer conditions with dry summers and wet

347 winters.

348 5. Conclusions

349 This study applied the MEP based ET model for the first time in a humid, low-energy

350 headwater catchment. The model generally gave plausible estimates of total

351 evapotranspiration and a first approximation of transpiration. The most encouraging

352 finding of this study is that it shows the potential of the MEP model for assessing

353 evaporation and transpiration under relatively uniform vegetation canopies, rather than

354 the sharply contrasting (i.e. bare soil/vegetated conditions in previous applications). In

355 the absence of measurements below the canopy it is difficult to precisely partition the

356 evaporation into canopy evaporation and understory $E T$, though in the current study the

357 latter is likely very small. Mixing of canopy evaporation and transpiration on wet days

358 is also hard to separate with the measuring techniques in this study, though again in this

359 case the effects are likely small and short in time. In total, over the study period, more 
360 than half of rainfall was returned to the atmosphere by $E T$, and the remaining percolated

361 to recharge soil and groundwater. Around one third of rainfall was lost through heather

362 transpiration and $22 \%$ as interception loss and understory ET. Heather shrublands, with

363 extensive spatial coverage play a crucial role in water flow and storage in Northern

364 upland. Understanding this role may assist land and water management in the future.

\section{Acknowledgements}

366 We would like to thank The Leverhulme Trust (project PLATO, RPG-2014-016) and

367 the European Research Council (ERC, project GA 335910 VeWa) for funding. We also

368 thank three anonymous reviewers for their invaluable comments that improved the

369 manuscript substantially. Data in this study can be accessed upon request to the authors.

\section{$370 \quad$ References}

371 Ala-aho P, Soulsby C, Wang H, Tetzlaff D. 2017. Integrated surface-subsurface model 372 to investigate the role of groundwater in headwater catchment runoff generation: a 373 minimalist approach to parameterisation. Journal of Hydrology DOI: $374 \quad 10.1016 /$ j.jhydrol.2017.02.023

375 Allen RG, Pereira LS, Raes D, Smith M. 1998. Crop evapotranspiration - Guidelines 376 for computing crop water requirements - FAO Irrigation and drainage paper 56. 377 Irrigation and Drainage: 1-15 DOI: 10.1016/j.eja.2010.12.001

378 Allen RG, Pruitt WO, Businger JA, Fritschen LJ, Jensen ME, Quinn FH. 1996. 379 Evaporation and Transpiration. In Hydrology HandbookAmerican Society of 380 Civil Engineers: New York, NY; 125-252. DOI: 10.1061/9780784401385.ch04 381 Baldocchi DD, Falge E, Gu L, Olson R, Hollinger D, Running S, Anthoni P, Bernhofer 382 C, Davis K, Evans R, et al. 2001. FLUXNET : A New Tool to Study the Temporal 383 and Spatial Variability of Ecosystem-Scale Carbon Dioxide, Water Vapor, and 384 Energy Flux Densities. Bulletin of the American Meteorological Society 82 385 (February): 2415-2434 DOI: 

10.1175/1520-0477(2001)082<2415:FANTTS $>2.3 . C O ; 2$

387

388

389

390

391

392

393

394

395

396

397

398

399

400

401

402

403

404

405

406

407

408

409

410

411

412

413

414

415

416

417

418

419

420

421

422

423

424

425

426

427
Birkel C, Soulsby C, Tetzlaff D. 2011. Modelling catchment-scale water storage dynamics: Reconciling dynamic storage with tracer-inferred passive storage. Hydrological Processes 25 (25): 3924-3936 DOI: 10.1002/hyp.8201

Blumstock M, Tetzlaff D, Dick JJ, Nuetzmann G, Soulsby C. 2016. Spatial organization of groundwater dynamics and streamflow response from different hydropedological units in a montane catchment. Hydrological Processes 30 (21): 3735-3753 DOI: 10.1002/hyp.10848

Bras RL. 2015. Complexity and organization in hydrology: A personal view. Water Resources Research 51 (8): 6532-6548 DOI: 10.1002/2015WR016958

Braun H, Tetzlaff D, Soulsby C, Weiler M. 2016. Influence of vegetation canopies on precipitation partitioning and isotope fractionation in northern upland catchments.EGU General Assembly, held 17-22 April, 2016: Vienna Austria; p.498.

Brutsaert W. 1982. Evaporation into the atmosphere: Theory, history, and applications. Springer Netherlands. DOI: 10.1007/978-94-017-1497-6

Calder IR. 1986. The influence of land use on water yield in upland areas of the U.K. Journal of Hydrology 88 (3-4): 201-211 DOI: 10.1016/0022-1694(86)90091-0

Calder IR, Hall RL, Harding RJ, Wright IR. 1984. The Use of a Wet-Surface Weighing Lysimeter System in Rainfall Interception Studies of Heather (calluna vulgaris). Journal of Climate and Applied Meteorology 23 (3): 461-473 DOI: Doi 10.1175/1520-0450(1984)023<0461:Tuoaws >2.0.Co;2

Cammalleri C, Ciraolo G, Minacapilli M, Rallo G. 2013. Evapotranspiration from an Olive Orchard using Remote Sensing-Based Dual Crop Coefficient Approach. Water Resources Management 27 (14): 4877-4895 DOI: 10.1007/s11269-013-0444-7

Caylor KK, D'Odorico P, Rodriguez-Iturbe I. 2006. On the ecohydrology of structurally heterogeneous semiarid landscapes. Water Resources Research 42 (7): n/a-n/a DOI: 10.1029/2005WR004683

Chen F, Manning KW, Lemone MA, Trier SB, Alfieri JG, Roberts R, Tewari M, Niyogi D, Horst TW, Oncley SP, et al. 2007. Description and evaluation of the characteristics of the NCAR high-resolution land data assimilation system. Journal of Applied Meteorology and Climatology 46 (6): 694-713 DOI: 10.1175/JAM2463.1

De Costa WAJM, Dennett MD, Biomass I, Index LA. 1992. Is Canopy Light Extinction Coefficient a Species - Specific Constant? Tropical Agricultural Research 4

Dunn SM, Mackay R. 1995. Spatial variation in evapotranspiration and the influence of land use on catchment hydrology. Journal of Hydrology 171 (1-2): 49-73 DOI: 10.1016/0022-1694(95)02733-6

Elmendorf SC, Henry GHR, Hollister RD, Björk RG, Boulanger-Lapointe N, Cooper EJ, Cornelissen JHC, Day TA, Dorrepaal E, Elumeeva TG, et al. 2012. Plot-scale evidence of tundra vegetation change and links to recent summer warming. Nature 

Climate Change 2 (6): 453-457 DOI: 10.1038/nclimate1465

Engstrom RN, Hope AS, Stow DA, Vourlitis GL, Oechel WC. 2002. Priestley-Taylor alpha coefficient: variability and relationship to NDVI in Arctic tundra landscapes. Journal of the American Water Resources Association 38 (6): 1647-1659 DOI: 10.1111/j.1752-1688.2002.tb04371.x

Gimingham CH. 1960. Calluna vulgaris (L.) Hull. Journal of Ecology 48 (2): 455-483 DOI: $10.2307 / 2257528$

Granier A. 1987. Evaluation of transpiration in a Douglas-fir stand by means of sap flow measurements. Tree Physiology 3 (0): 309-320

Haria AH, Price DJ. 2000. Evaporation from Scots pine (Pinus sylvestris) following natural re-colonisation of the Cairngorm mountains, Scotland. Hydrology and Earth System Sciences 4 (3): 451-461 DOI: 10.5194/hess-4-451-2000

Hu Z, Yu G, Fu Y, Sun X, Li Y, Shi P, Wang Y, Zheng Z. 2008. Effects of vegetation control on ecosystem water use efficiency within and among four grassland ecosystems in China. Global Change Biology 14 (7): 1609-1619 DOI: 10.1111/j.1365-2486.2008.01582.x

van Huijgevoort MHJ, Tetzlaff D, Sutanudjaja EH, Soulsby C. 2016. Using high resolution tracer data to constrain water storage, flux and age estimates in a spatially distributed rainfall-runoff model. Hydrological Processes 30 (25): 47614778 DOI: 10.1002/hyp.10902

IPCC. 2014. Summary for Policymakers. In Climate Change 2014: Impacts, Adaptation, and Vulnerability. Part A: Global and Sectoral Aspects. Contribution of Working Group II to the Fifth Assessment Report of the Intergovernmental Panel on Climate Change1-32. DOI: 10.1016/j.renene.2009.11.012

Johnson R. 1991. Effects of upland afforestation on water resources. The Balquhidder experiment 1981-1991. In Report-- Institute of Hydrology.

Kool D, Agam N, Lazarovitch N, Heitman JL, Sauer TJ, Ben-Gal A. 2014. A review of approaches for evapotranspiration partitioning. Agricultural and Forest Meteorology 184: 56-70 DOI: 10.1016/j.agrformet.2013.09.003

Ladekarl UL, Rasmussen KR, Christensen S, Jensen KH, Hansen B. 2005. Groundwater recharge and evapotranspiration for two natural ecosystems covered with oak and heather. Journal of Hydrology 300 (1-4): 76-99 DOI: 10.1016/j.jhydrol.2004.05.003

Li L, Li X-Y, Zhang S-Y, Jiang Z-Y, Zheng X-R, Hu X, Huang Y-M. 2016. Stemflow and its controlling factors in the subshrub Artemisia ordosica during two contrasting growth stages in the Mu Us sandy land of northern China. Hydrology Research 47 (2): 409-418 DOI: 10.2166/nh.2015.253

Lindner M, Garcia-Gonzalo J, Kolström M, Green T, Reguera R, Maroschek M, Seidl R, Lexer MJ, Netherer S, Schopf A, et al. 2008. Impacts of Climate Change on European Forests and Options for Adaptation

Liston GE, Elder K. 2006. A Meteorological Distribution System for High-Resolution Terrestrial Modeling (MicroMet). Journal of Hydrometeorology 7 (2): 217-234 
DOI: $10.1175 / \mathrm{JHM} 486.1$

Llorens P, Domingo F. 2007. Rainfall partitioning by vegetation under Mediterranean conditions. A review of studies in Europe. Journal of Hydrology 335 (1-2): 37-54 DOI: $10.1016 /$ j.jhydrol.2006.10.032

Lu X, Liang LL, Wang L, Jenerette GD, McCabe MF, Grantz DA. 2017. Partitioning of evapotranspiration using a stable isotope technique in an arid and high temperature agricultural production system. Agricultural Water Management 179: 103-109 DOI: 10.1016/j.agwat.2016.08.012

MacDonald AJ, Kirkpatrick AH, Hester AJ, Sydes C. 1995. Regeneration by natural layering of heather (Calluna vulgaris): frequency and characteristics in upland Britain. Journal of Applied Ecology 32 (1): 85-99 DOI: 10.2307/2404418

Miralles DG, De Jeu RAM, Gash JH, Holmes TRH, Dolman AJ. 2011. Magnitude and variability of land evaporation and its components at the global scale. Hydrology and Earth System Sciences 15 (3): 967-981 DOI: 10.5194/hess-15-967-2011

Miranda AC, Jarvis PG, Grace J. 1984. Transpiration and evaporation from heather Moorland. Boundary-Layer Meteorology 28 (3-4): 227-243 DOI: 10.1007/BF00121306

$\mathrm{Mu} \mathrm{Q}$, Zhao M, Running SW. 2011. Improvements to a MODIS global terrestrial evapotranspiration algorithm. Remote Sensing of Environment 115 (8): 17811800 DOI: 10.1016/j.rse.2011.02.019

Myneni R, Park YKT. 2015. MCD15A2H MODIS/Terra+Aqua Leaf Area Index/FPAR 8-day L4 Global 500m SIN Grid V006. NASA EOSDIS Land Processes DAAC Available at: https://doi.org/10.5067/MODIS/MCD15A2H.006

Noilhan J, Planton S. 1989. A Simple Parameterization of Land Surface Processes for Meteorological Models. Monthly Weather Review 117 (3): 536-549 DOI: 10.1175/1520-0493(1989)117<0536:ASPOLS >2.0.CO;2

Priestley CHB, Taylor RJ. 1972. On the Assessment of Surface Heat Flux and Evaporation Using Large-Scale Parameters. Monthly Weather Review 100 (2): 81-92 DOI: 10.1175/1520-0493(1972)100<0081:OTAOSH>2.3.CO;2

Ritchie JT. 1972. Model for predicting evaporation from a row crop with incomplete cover. Water Resources Research 8 (5): 1204-1213 DOI: 10.1029/WR008i005p01204

Robinson M, Moore RE, Nlsbet TR, Blackle JR. 1998. From moorland to forest : the Coalburn catchment experiment. (133): 24-27 Available at: http://nora.nerc.ac.uk/7372/1/IH_133.pdf [Accessed 12 June 2017]

Rosa RD, Ramos TB, Pereira LS. 2016. The dual Kc approach to assess maize and sweet sorghum transpiration and soil evaporation under saline conditions: Application of the SIMDualKc model. Agricultural Water Management 177: 7794 DOI: 10.1016/j.agwat.2016.06.028

Ross J. 1981. The radiation regime and architecture of plant stands. In Tasks for Vegetation Sciences 3, LIETH H (ed.).Springer Netherlands: Dordrecht; 391. DOI: 10.1007/978-94-009-8647-3 
Schlesinger WH, Jasechko S. 2014. Transpiration in the global water cycle. Agricultural and Forest Meteorology 189-190: 115-117 DOI: 10.1016/j.agrformet.2014.01.011

Serreze MC, Barry RG. 2011. Processes and impacts of Arctic amplification: A research synthesis. Global and Planetary Change 77 (1-2): 85-96 DOI: 10.1016/j.gloplacha.2011.03.004

Shuttleworth WJ, Wallace JS. 1985. Evaporation From Spare Crops - An Energy Combination Theory. Quarterly Journal of The Royal Meteorological Society 111 (469): 839-855 DOI: 10.1002/qj.49711146910

Shwetha HR, Kumar DN. 2015. Prediction of Land Surface Temperature Under Cloudy Conditions Using Microwave Remote Sensing and ANN. Aquatic Procedia 4 (Icwrcoe): 1381-1388 DOI: 10.1016/j.aqpro.2015.02.179

Šimůnek J, Genuchten M Van, Sejna M. 2012. HYDRUS: Model use, calibration, and validation. Transactions of the ASABE 55 (1987): 1261-1274 DOI: 10.1029/2002WR001340

Soulsby C, Birkel C, Geris J, Dick J, Tunaley C, Tetzlaff D. 2015. Stream water age distributions controlled by storage dynamics and nonlinear hydrologic connectivity: Modeling with high-resolution isotope data. Water Resources Research 51 (9): 7759-7776 DOI: 10.1002/2015WR017888

Soulsby C, Bradford J, Dick J, P. McNamara J, Geris J, Lessels J, Blumstock M, Tetzlaff D. 2016. Using geophysical surveys to test tracer-based storage estimates in headwater catchments. Hydrological Processes DOI: 10.1002/hyp.10889

Sprenger M, Tetzlaff D, Soulsby C. 2017. Stable isotopes reveal evaporation dynamics at the soil-plant-atmosphere interface of the critical zone. Hydrology and Earth System Sciences Discussions (February): 1-37 DOI: 10.5194/hess-2017-87

Stewart H, Hewitt CN, Bunce RGH. 2008. Assessing, mapping and quantifying the distribution of foliar biomass in Great Britain. Biomass and Bioenergy 32 (9): 838-856 DOI: 10.1016/j.biombioe.2007.12.015

Sutanto SJ, Wenninger J, Coenders-Gerrits AMJ, Uhlenbrook S. 2012. Partitioning of evaporation into transpiration, soil evaporation and interception: A comparison between isotope measurements and a HYDRUS-1D model. Hydrology and Earth System Sciences 16 (8): 2605-2616 DOI: 10.5194/hess-16-2605-2012

Tetzlaff D, Birkel C, Dick J, Geris J, Soulsby C. 2014. Storage dynamics in hydropedological units control hillslope connectivity, runoff generation, and the evolution of catchment transit time distributions. Water resources research $\mathbf{5 0}$ (2): 969-985 DOI: 10.1002/2013WR014147

Tetzlaff D, Buttle J, Carey SK, van Huijgevoort MHJ, Laudon H, McNamara JP, Mitchell CPJ, Spence C, Gabor RS, Soulsby C. 2015. A preliminary assessment of water partitioning and ecohydrological coupling in northern headwaters using stable isotopes and conceptual runoff models. Hydrological Processes: n/a-n/a DOI: 10.1002/hyp.10515

Tetzlaff D, Soulsby C, Waldron S, Malcolm IA, Bacon PJ, Dunn SM, Lilly A, 
Youngson AF. 2007. Conceptualization of runoff processes using a geographical information system and tracers in a nested mesoscale catchment. Hydrological Processes 21 (10): 1289-1307 DOI: 10.1002/hyp.6309

Wallace JS, Roberts JM, Roberts AM. 1982. Evaporation from heather moorland in north Yorkshire, England. Hydrological research basins and their use in water resources planning: proceedings of the international symposium held in Berne, Switzerland September 21-23, 1982 Available at: http://agris.fao.org/agris-search/search.do?recordID=US201301444022 [Accessed 25 May 2017]

Wang H, Guan H, Deng Z, Simmons CT. 2014. Optimization of canopy conductance models from concurrent measurements of sap flow and stem water potential on Drooping Sheoak in South Australia. Water Resources Research 50 (7): 61546167 DOI: $10.1002 / 2013$ WR014818

Wang H, Tetzlaff D, Dick JJ, Soulsby C. 2017. Assessing the environmental controls on Scots pine transpiration and the implications for water partitioning in a boreal headwater catchment. Agricultural and Forest Meteorology 240-241: 58-66 DOI: 10.1016/j.agrformet.2017.04.002

Wang J, Bras RL. 2009. A model of surface heat fluxes based on the theory of maximum entropy production. Water Resources Research 45 (11): n/a-n/a DOI: 10.1029/2009WR007900

Wang J, Bras RL. 2011. A model of evapotranspiration based on the theory of maximum entropy production. Water Resources Research 47 (3): n/a-n/a DOI: 10.1029/2010WR009392

Weiß M, Menzel L. 2008. A global comparison of four potential evapotranspiration equations and their relevance to stream flow modelling in semi-arid environments. Adv. Geosci 18: 15-23 Available at: www.adv-geosci.net/18/15/2008/ [Accessed 29 May 2017]

Wilcox BP, Dowhower SL, Teague WR, Thurow TL. 2006. Long-Term Water Balance in a Semiarid Shrubland. Rangeland Ecology \& Management 59 (November): 600-606 DOI: 10.2111/06-014R3.1

Yang Y, Shang S. 2013. A hybrid dual-source scheme and trapezoid framework-based evapotranspiration model (HTEM) using satellite images: Algorithm and model test. Journal of Geophysical Research: Atmospheres 118 (5): 2284-2300 DOI: 10.1002/jgrd.50259

Yang Y, Guan H, Hutson JL, Wang H, Ewenz C, Shang S, Simmons CT. 2013. Examination and parameterization of the root water uptake model from stem water potential and sap flow measurements. Hydrological Processes 27: 2857-2863 DOI: 10.1002/hyp.9406

Yu M, Wang G, Parr D, Ahmed KF. 2014. Future changes of the terrestrial ecosystem based on a dynamic vegetation model driven with RCP8.5 climate projections from 19 GCMs. Climatic Change 127 (2): 257-271 DOI: $10.1007 / \mathrm{s} 10584-014-1249-2$ 
596 Zhang L, Hu Z, Fan J, Zhou D, Tang F. 2014. A meta-analysis of the canopy light 597 extinction coefficient in terrestrial ecosystems. Frontiers of Earth Science 8 (4): 598 599-609 DOI: 10.1007/s11707-014-0446-7

599 
Table 1 Daily average ( \pm one standard deviation) of measured (rainfall) and estimated (evapotranspiration, transpiration, evaporation, and deep percolation) water balance components. Percentage of rainfall of total amount of each component over the study periods is also given below.

\begin{tabular}{lccccc}
\hline & \multicolumn{2}{c}{ Daily average $(\mathbf{m m} / \mathbf{d})$} & \multicolumn{3}{c}{ Percent of rainfall } \\
\cline { 2 - 6 } & $31 / 07-$ & $21 / 04-$ & $31 / 07-$ & $21 / 04-$ & $\begin{array}{c}\text { Entire } \\
\text { period }\end{array}$ \\
\hline Rainfall & $1.80 \pm 3.2$ & $2.76 \pm 5.8$ & & & \\
\hline Evapotranspiration & $0.91 \pm 0.6$ & $1.51 \pm 0.7$ & $50.4 \%$ & $54.9 \%$ & $53.3 \%$ \\
\hline Transpiration & $0.53 \pm 0.3$ & $0.89 \pm 0.4$ & $29.2 \%$ & $32.3 \%$ & $31.2 \%$ \\
\hline Evaporation & $0.38 \pm 0.3$ & $0.62 \pm 0.3$ & $21.2 \%$ & $22.6 \%$ & $22.1 \%$ \\
\hline Percolation & $0.89 \pm 3.5$ & $1.24 \pm 6.2$ & $49.6 \%$ & $45.1 \%$ & $46.7 \%$
\end{tabular}




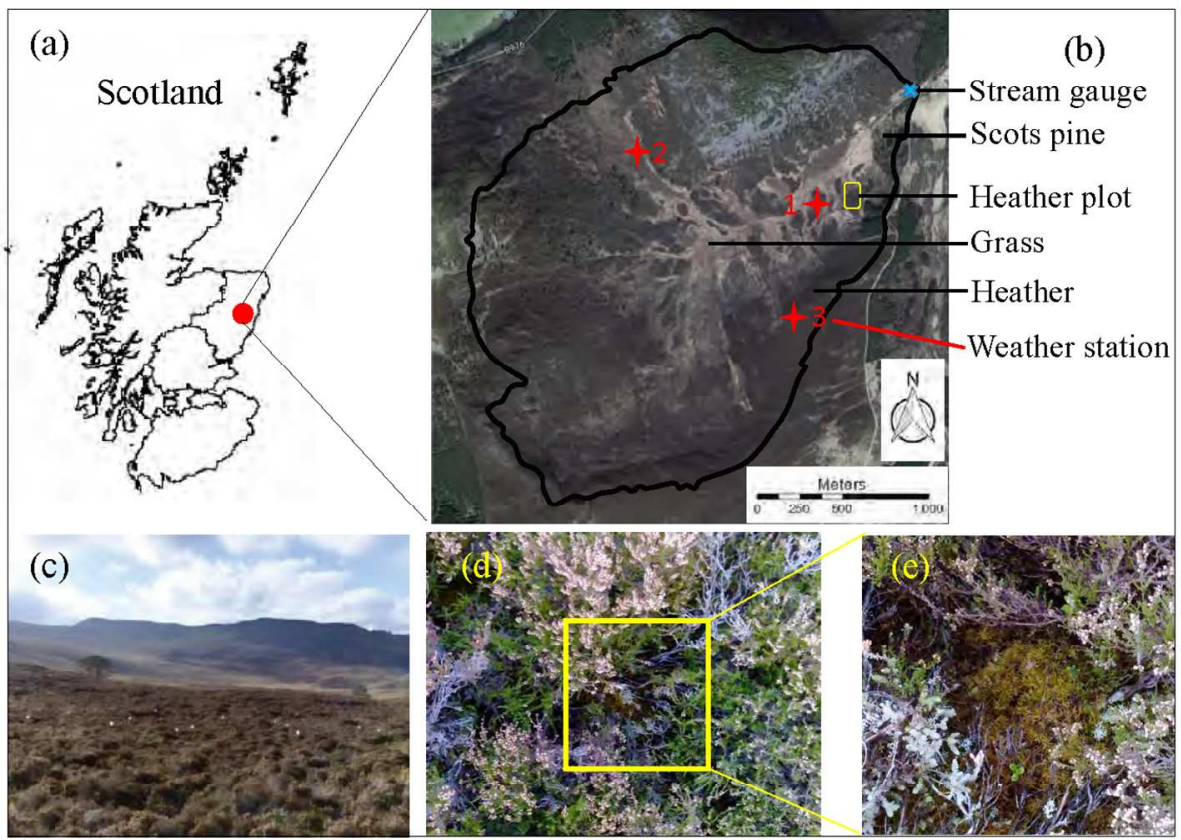

Figure 1 (a) Location of the Bruntland Burn catchment on the map of Scotland; (b) Aerial photo of the catchment showing three major vegetation types in green (Scots pine), dark brown (heather), and light brown (grass), and locations of 3 weather stations, heather plot in this study, and stream gauge at the outlet; (c) Heather plot with iButton sensors hanging right above canopies; (d) Heather canopies in December 2016; and (e) Moss cover under heather at soil surface.

$254 \times 190 \mathrm{~mm}(150 \times 150 \mathrm{DPI})$ 
Figure 2 Daily dynamics of hydroclimatic variables at the weather station \#1. (a) Air temperature (Ta), relative humidity $(R H)$, and rainfall $(P)$; (b) Net radiation $(R n)$ and potential evapotranspiration $(p E T)$. $p E T_{P T}$ is $p E T$ calculated using the Priestley-Taylor equation, and $p E T_{P M}$ is $p E T$ calculated using the Penman-Monteith equation. The gap separates the two measurement periods in 2015 and 2016.

$227 \times 119 \mathrm{~mm}(300 \times 300 \mathrm{DPI})$ 


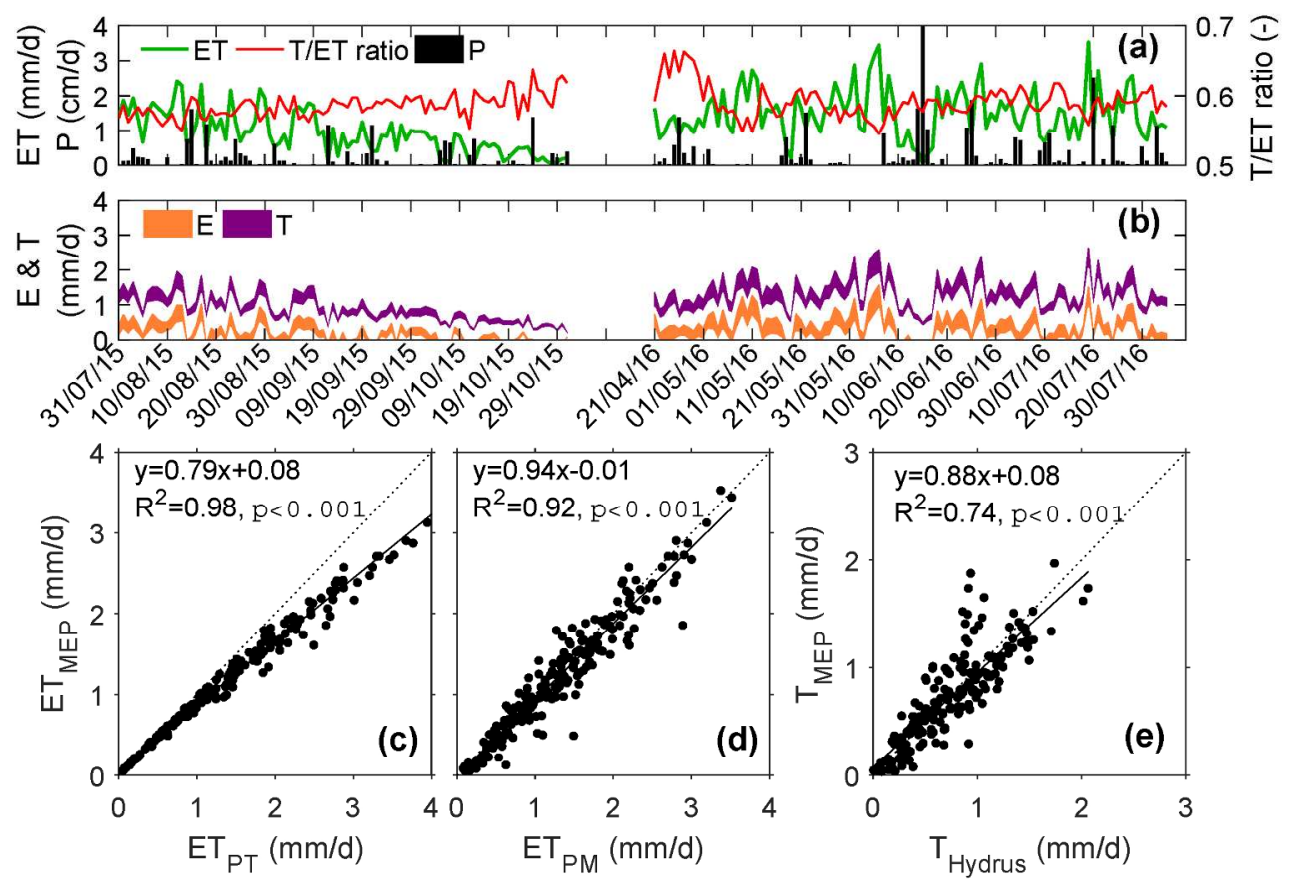

Figure 3 (a) Daily dynamics of evapotranspiration $(E T), T / E T$ ratio and precipitation $(P)$. (b) daily dynamics of evaporation $(E)$ and transpiration $(T)$. The bands of $E$ and $T$ give the upper and lower limits estimated based on daily standard deviation of temperature and humidity. The gap separates the two periods in 2015 and 2016. (c-d) Comparisons of ET estimated from the MEP model, FAO crop coefficient method with potential $E T$ calculated by Priestley-Taylor and Penman-Monteith equations respectively. (e) Comparison of $T$ by the MEP model and Hydrus-1D model. Dashed lines are 1:1 lines. Solid lines are from linear regression.

$217 \times 145 \mathrm{~mm}(300 \times 300$ DPI $)$ 